\title{
24
}

Rupantaran : A Multidisciplinary Journal

Vol. III : 24-33, March, 2020

ISSN : 2091-0061

Research Management Cell (RMC)

Dhankuta Multiple Campus, Dhankuta

Tribhuvan University, Nepal

\section{Socio-Economic and Demographic Study in Majhi Community}

\author{
Ganesh Bimali ${ }^{1}$ \\ Email: bimaliji007@gmail.com
}

\begin{abstract}
Majhi community is completely soc- economically backward community. This article is focused on social-economic and demographic study in Majhi. The sample size is selected all (41) HHs of study area (ward no 4 and 5 of Aatharai Rural Municipality) by using census sampling. Both primary and secondary sources have been used.The open ended and closed ended questionnaire were designed to complete this study. The collected information were analyzed and interpreted with quantitative way by mean, ratio and percentage using SPSS (Statistical package for social science). The data were collected through head of household or responsible person of household. The Majhi people of study area have poor educational status, they changed their occupation boating, fishing to agriculture, foreign employment which changed their income level. Demographically, the numbers of female are more than male; life expectancy is very low due to few number of age over 60 and high number of less than age 15 population. The study help to find the real socio-economic and regional situation of Majhi people in regional or of specific area.
\end{abstract}

Key words: Majhi community, socio-economic, demographic, education

\section{Introduction}

Majhi is a minority as an indigenous caste / ethnic community among the 125 castes / ethnic groups of Nepal. There are 206000 Majhi are living in the world (Surya, 2018). The 83727 Majhis are one of the indigenous peoples inNepal who are living in their own language, dress, culture, etc (GoN, 2014). Majhi is not only polite and shy but also very much friendly and helpful. Majhi have had a special and intimate relationship with the rivers of Nepal. The main traditional occupation of the Majhi people is boating, building and river transportation services in Nepal. (http://www.

1. Mr. Bimali is a teaching assistant of Population Studies at Tribhuvan University, Terhathum Multiple Campus, Terhathum. 
indigenousvoice.com/en/indigenous-peoples/13/majhi.html). The fertility behavior is determined by their social and cultural norms and values as well as education and economic status. Education plays a vital role in human life. The Majhi have limited educational opportunities. They have very low literacy level, no Majhi has a Master's degree, only 15 have bachelor's degrees, 35 have certificate level qualifications and 130 have the qualification of S.L.C. (School Leaving Certificate) (Surya, 2018). Millennium development goals and sustainable development goals focused in zero hunger, no poverty good health, education for all, reduced inequality among the all people of the world (UNDP, 2020).

The study, only Majhi has been taken which is completely socially and economically backward community. In general, educational attainment, occupational and income status, age at marriage, child loss experience determined the status of Majhi people. The CBS (2014) studied the socio-economic situation of Majhi at National level. But there is not properly studied about it in the regional or specific area. Therefore, this study aims to identify the demographic and socio-economic characteristic of Majhi community.

\section{Methods and Materials}

In the study area was purposively selected the Majhi community in ward no 4 and 5 (Iwa and Chhatedhunga) Aatharai Rural Municipality of Terhathum District. All of the Majhi HHs (41) of the study area were selected as a study population by census methods. The nature of the study is used descriptive. Both primary and secondary sources have been used.The open ended and closed ended questionnaire were designed to complete this study. The collected information were analyzed and interpreted with quantitative way by mean, ratio and percentage using SPSS (Statistical package for social science). The data were collected through head of household or responsible person of household.

\section{Results and Discussions}

This study deals the general demographic and socio-economic characteristics of Majhi people in Aatharai Rural Municipality, which may represent socio-economic status among Majhi community.

\section{Results}

\section{Age and sex structure of the study population}

Age and sex structure of population are important variables for studying socioeconomic and demographic impact on fertility because age and sex structure not only reflect the present demographic scenario of population, but also provide the basis for the study of the past as well as future demographic scenario of the population. The table shows that age and sex structure of the study population in Majhi community. 
Table 1: Age-Sex Distribution of Study Population

\begin{tabular}{|c|c|c|c|c|c|c|c|}
\hline \multirow{2}{*}{$\begin{array}{c}\text { Age } \\
\text { group }\end{array}$} & \multicolumn{2}{|c|}{ Male } & \multicolumn{2}{|c|}{ Female } & \multicolumn{2}{|c|}{ Total } & \multirow{2}{*}{$\begin{array}{c}\text { Sex } \\
\text { Ratio } \\
\end{array}$} \\
\hline & Number & Percent & Number & Percent & Number & Percent & \\
\hline $0-4$ & 14 & 9.72 & 20 & 12.20 & 34 & 12.04 & 70 \\
\hline $5-9$ & 20 & 13.89 & 21 & 12.80 & 41 & 13.31 & 95 \\
\hline $10-14$ & 18 & 12.50 & 19 & 11.59 & 37 & 13.01 & 94.7 \\
\hline $15-19$ & 14 & 9.72 & 17 & 10.37 & 31 & 10.06 & 82.35 \\
\hline $20-24$ & 11 & 7.64 & 15 & 9.15 & 26 & 8.44 & 73.33 \\
\hline $25-29$ & $\overline{14}$ & 9.72 & 16 & 9.76 & 30 & 9.74 & 87.5 \\
\hline $30-34$ & 11 & 7.64 & 11 & 6.71 & 22 & 7.14 & 100 \\
\hline $35-39$ & $\overline{12}$ & 8.33 & 10 & 6.10 & $\overline{22}$ & 7.14 & 120 \\
\hline $40-44$ & $\overline{9}$ & 6.25 & 9 & 5.49 & 18 & 4.84 & 100 \\
\hline $45-49$ & 9 & 6.25 & 11 & 6.71 & 20 & 5.49 & 81.8 \\
\hline $50-54$ & 5 & 3.47 & 6 & 3.66 & 11 & 3.57 & 83.3 \\
\hline $55-59$ & 3 & 2.08 & 4 & 2.44 & 7 & 2.21 & 75 \\
\hline $60+$ & 4 & 2.78 & 5 & 3.05 & 9 & 2.92 & 80 \\
\hline Total & 144 & 100.00 & 164 & 100.00 & 308 & 100.00 & 87.8 \\
\hline
\end{tabular}

Source: Field Survey, 2018

This study covers the population of 308 taken from $41 \mathrm{HHs}$. Out of the total population, 47 percent were males and 53 percent females. Table no. 1 indicates that the highest proportion of population lies in age group 5-9 (13.31\%) followed by age group 10-14 (12\%). This indicates that higher proportion of population in the lower age indicated the high fertility. The lowest proportion of population was found in age group $55-59(2.27 \%)$ and age group 60 above (2.92) of study population. It is indicating low life expectancy at birth. In age group 0-14 and 60 above is found 36.36 percent and 2.92 percent respectively whereas the population in age group 15-59 is found as 61 percent which is higher than the earlier two age groups (0-14 and 60 years above).

\section{Educational status of study population}

The education is considered as the main element to determine socio-economic and demographic status of fertility. According to census 2011 in Nepal literacy rate is 65.9 percent (75.1\% male and $57.4 \%$ female) which was 53.74 percent in 2001 .

Table 2: Distribution of Population of 6 years and above by Sex and Educational Status

\begin{tabular}{|l|r|r|r|r|r|r|}
\hline \multirow{2}{*}{ Level } & \multicolumn{2}{|c|}{ Male } & \multicolumn{2}{c|}{ Female } & \multicolumn{2}{c|}{ Total } \\
\cline { 2 - 7 } & Number & Percent & Number & Percent & Number & \multicolumn{1}{c|}{ Percent } \\
\hline Literate & 94 & 65.28 & 94 & 57.32 & 188 & 61.04 \\
\hline Illiterate & 50 & 34.72 & 70 & 42.68 & 120 & 38.96 \\
\hline Total & 144 & 100.00 & 164 & 100.00 & 308 & 100.00 \\
\hline Among Literate & \multicolumn{9}{|c|}{} \\
\hline In-formal & 11 & 11.70 & 37 & 34.04 & 48 & 25.53 \\
\hline Primary(1-8) & 65 & 69.15 & 55 & 53.19 & 110 & 58.51 \\
\hline Secondary(9-12) & 18 & 19.15 & 12 & 12.77 & 30 & 15.96 \\
\hline Total & 94 & 100.00 & 94 & 100.00 & 188 & 100.00 \\
\hline
\end{tabular}


Table no. 2 depicts that a large number of people are illiterate $120(38.96 \%)$, among them female illiteracy rate 70(42\%) which is higher than male i.e. $94(35 \%)$, furthermore among the literate 188 people, the highest percent $110(58.51 \%)$ is found in primary level of education whereas male $65(69 \%)$ and female 55(53\%). Similarly in-formal education is higher women 37 than male 11. The lowest proportion is found in the secondary level. It is interesting that there are no more Majhi people involved in higher education.

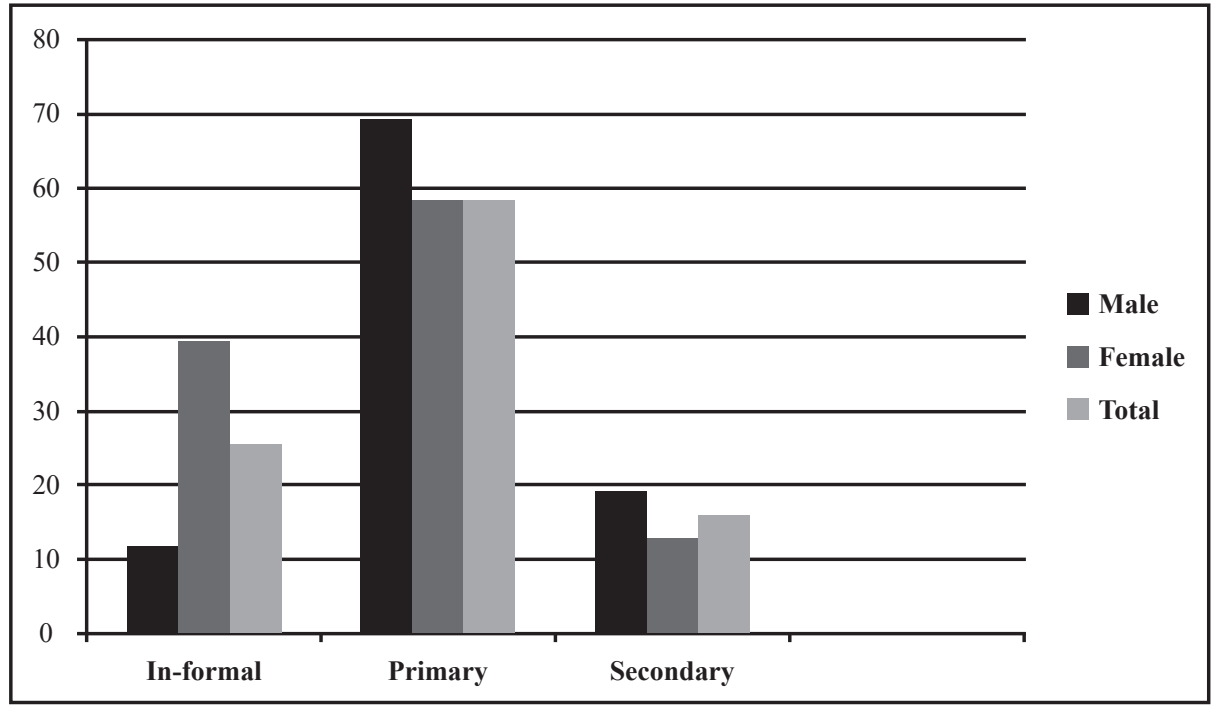

Figure 1: Distribution of Literate People by Educational Level

Source: Field Survey, 2018

\section{Marital status in study areas}

This study deals the frequency, characteristics and dissolution of marriage in Majhi community in the study area. It plays a vital role in determining the fertility because family function is started after the marriage where birth is impossible without marriage. It directly affects fertility of everywhere population and the marital status in the study area is given below.

Table 3: Distribution of Population of 15 years \& above by sex and Marital Status

\begin{tabular}{|l|r|r|r|r|r|r|}
\hline \multirow{2}{*}{ Marital Status } & \multicolumn{2}{|c|}{ Male } & \multicolumn{2}{c|}{ Female } & \multicolumn{2}{c|}{ Total } \\
\cline { 2 - 7 } & Number & Percent & Number & Percent & Number & Percent \\
\hline Unmarried & 56 & 38.89 & 79 & 48.17 & 135 & 43.83 \\
\hline Married & 83 & 57.64 & 72 & 43.90 & 155 & 50.32 \\
\hline Widow/Widower & 4 & 2.78 & 11 & 6.71 & 15 & 4.87 \\
\hline Separated & 1 & 0.69 & 2 & 1.22 & 3 & 0.97 \\
\hline Total & 144 & 100.00 & 164 & 100.00 & 308 & 100.0 \\
\hline
\end{tabular}


The table no. 3 shows that highest proportion of the married people 50.32 and little bit difference of unmarried population 43.83 percent and only 5 percent widower/ widow and 0.97 percent separated. Female are excess in both widow/widower and separated.

\section{Religion and mother tongue in study area}

Nepal is ethnic diverse country, it is influencing after the onset of multiparty democracy in Nepal since, 1990. Society information on religion was started to take from 1952/54 census in Nepal. The study population was only found Hindu. Similarly, their mother tongue is Majhi but all of them used the Nepali language.

\section{Type of family in study area}

Type of family is one main socio-economic variable which plays the role indirectly in their fertility behavior. In joint family, child bearing and take caring responsibility complete by senior members but in nuclear family such type of responsibility is with child's parents themselves. So, obviously joint family has high fertility rather than nuclear family.

Table 4: Distribution of Type of Family

\begin{tabular}{|l|r|r|}
\hline \multicolumn{1}{|c|}{ Family Type } & Number & \multicolumn{2}{c|}{ Percent } \\
\hline Nuclear & 20 & 49.2 \\
\hline Joint & 21 & 50.8 \\
\hline Total & 41 & 100.0 \\
\hline
\end{tabular}

Source: Field Survey, 2018

Table number 4 shows that, out of total $41(50.8 \%)$ people are in nuclear family and 49.2 percent people are in joint family at study area.

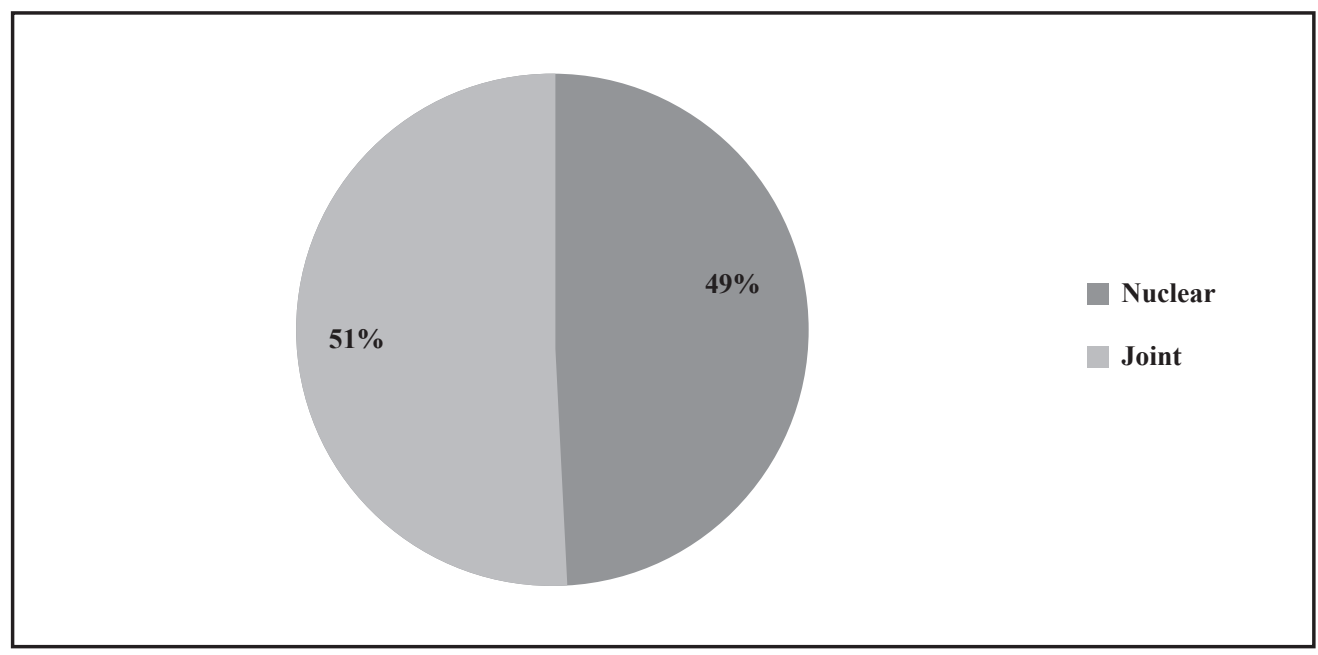

Fig. 2: Distribution of Type of Family 


\section{Main source of income in study area}

Economic status of household is that factor which determined the children's education, health as well as for their quality of life which directly or indirectly affects on fertility. The Majhi have own specific sources of income from the historic movement. They involved in boating and fishing in the ancestral occupation. But, now they completely have changed their occupation of sources of income. The distribution of main income source of household in study area is given below table.

Table 5: Distribution of Respondents' Households by Main Source of Income

\begin{tabular}{|l|r|r|r|r|}
\hline \multicolumn{3}{|c|}{ Past income sources } & \multicolumn{1}{c|}{ Current income sources } \\
\hline & Frequency & Percent & Frequency & \multicolumn{1}{c|}{ Percent } \\
\hline Fishing & 13 & 31.71 & 4 & 9.76 \\
\hline Agriculture & 5 & 12.20 & 20 & 48.79 \\
\hline Both agriculture and fishing & 10 & 24.40 & - & - \\
\hline Boating & 10 & 24.40 & - & - \\
\hline Daily wages & 3 & 7.32 & 2 & 4.88 \\
\hline Foreign employment & - & - & 15 & 36.58 \\
\hline Total & 41 & 100.0 & 41 & 100.00 \\
\hline
\end{tabular}

Source: Field Survey, 2018

The table 5 presents that the agriculture is the main source of Majhi community in present but fishing was highest occupied of these people in the past. Also foreign employment is an attractive source of income of Majhi people in present. Most of the respondents deal that fishing (31.71\%) and boating (24.40\%), agriculture and fishing $(24.40 \%)$ and agriculture only $(12.20 \%)$ were main sources of household income in the past. But, now days agriculture is about fifty percent sources of income of households, the foreign labour Migration is (36\%) and little bit people are involving fishing $(10 \%)$ and daily wages $(5 \%)$ express their main source of income. This fact presents that changing the dimension of sources of income in Majhi household from boating fishing to foreign labour migration and agriculture.

\section{Annual income in the study area}

Annual income is a main indicator of poverty. The National Planning Commission (2073) identified that 21.6 percent of the people are living under the poverty line. The main indicators of the poverty are also annual income and sufficiency of food. In this study, respondents were also asked about the annual income. Table 4.6 shows that only $(7.32 \%)$ household do not have any annual income in the past years. But 66 percent house hold head have reported less than one thousand annual income in past year and 27 percent have 1-5 thousands annual income in past years. Majority 43.9 percentage of respondents reported that they have saved 5-10 thousands annual income after shifting occupation now a day. Similarly, above 10 thousands saved 
annual income from 29.27 percent and 27.0 percent have less than 5 thousands annual income. These result proved that changing the annual income of the Majhi community with the changing the occupation status of Majhi people and also it focused that the changing the socio economic status of Majhi people.

Table 6: Distribution of Households by Annual Income level

\begin{tabular}{|l|r|r|r|r|r|}
\hline \multicolumn{2}{|c|}{ Past annual income of household } & \multicolumn{3}{c|}{ Present annual income of house } \\
\hline & Number & Percent HH & & Number HH & Percent \\
\hline No & 3 & 7.32 & less than5000 & 11 & 26.83 \\
\hline less than 1000 & 27 & 65.85 & $5000-10000$ & 18 & 43.90 \\
\hline $1000-5000$ & 11 & 26.83 & 10000 above & 12 & 29.27 \\
\hline Total & 41 & 100.00 & Total & 41 & 100.00 \\
\hline
\end{tabular}

Source: Field Survey, 2018

\section{Size of land holding}

It has already stated that agriculture is main occupation of Majhi households in this study area. The size of their land holding is given below the table.

Table 7: Distribution of Respondents' Households by Size of Land Holding

\begin{tabular}{|l|r|r|}
\hline \multicolumn{1}{|c|}{ Area } & Frequency & \multicolumn{2}{c|}{ Percent } \\
\hline Yes & 38 & 92.68 \\
\hline No & 3 & 7.32 \\
\hline Total & 41 & 100.00 \\
\hline If Yes & & 42.10 \\
\hline less than 10 ropani & 16 & 44.73 \\
\hline 10-20 ropani & 17 & 13.16 \\
\hline More than 20 ropani & 5 & 100.00 \\
\hline Total & 38 & \\
\hline
\end{tabular}

Source: Field Survey, 2018

From the above Table 7, it was found that among 41 household in study area, 38 houses $(92.68 \%)$ have land holding. Among the 38 respondents house $(42.10 \%)$ have the size of land holding less than 10 ropani, 44.73 percent respondents house have the size of land holding 10-20 ropani and (13.16\%) percent respondents house have more than 20 ropani size of land holding in study area. 


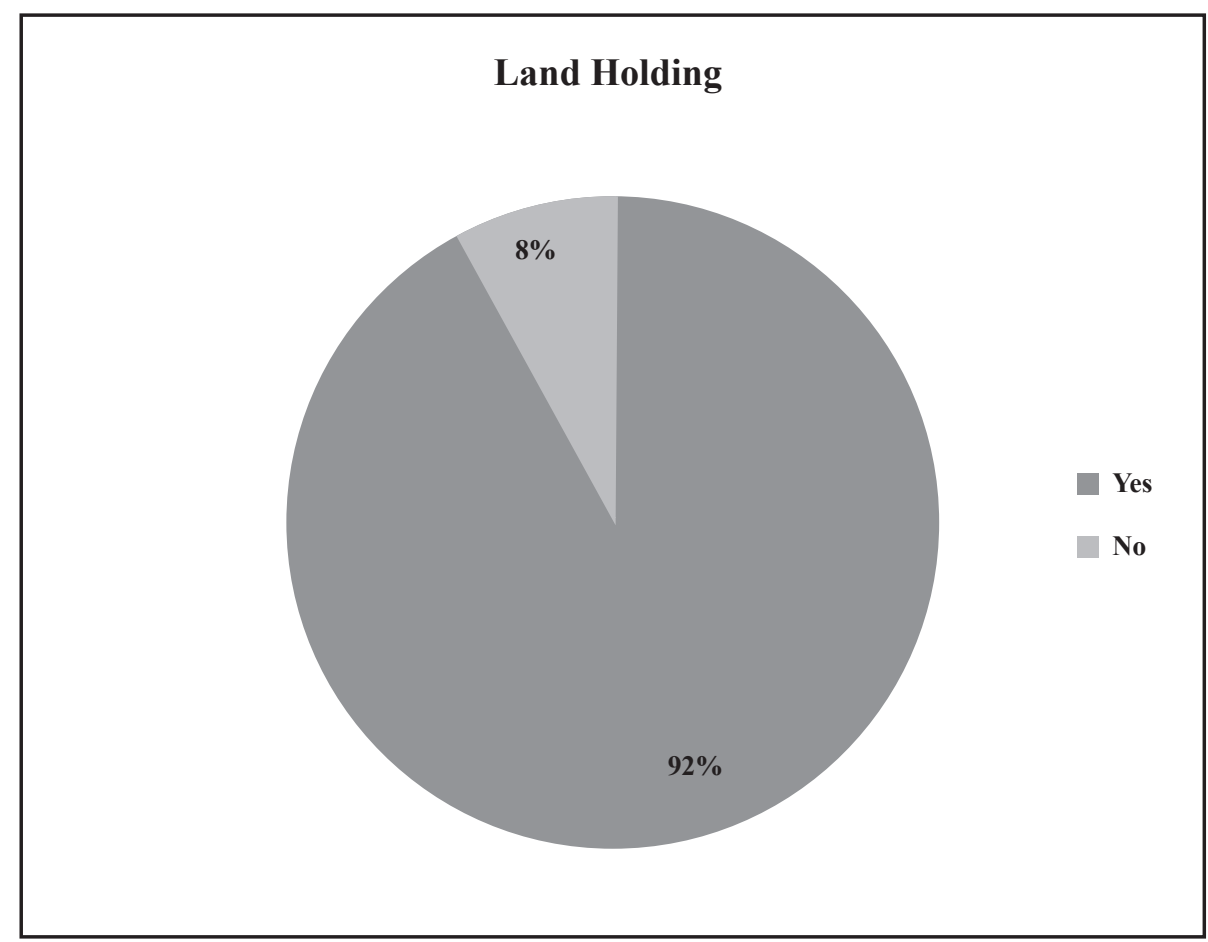

Figure 3: Distribution of Land Holding

\section{Food sufficiency of household from own farm land}

Food sufficiency of household is a main indicator for good health. In general, if the households do not have sufficient food from their own land, then people are compelled to engage in any type of activity. Their economic condition may be poor and pathetic. They do not have any means of relax.

Table 8: Distribution of Households by Food Sufficiency from Own Land

\begin{tabular}{|l|r|r|}
\hline \multicolumn{1}{|c|}{ Food distribution } & Frequency & \multicolumn{2}{c|}{ Percent } \\
\hline Yes & 16 & 60.98 \\
\hline No & 25 & 100.00 \\
\hline Total & 41 & \multicolumn{2}{|c|}{ Source: Field Survey, 2018} \\
\hline
\end{tabular}

According to table no. 3.8 out of 41 house of respondents 60.98 percent have not sufficiency of food from their own farm land for the whole year and 39.02 percent respondents house have sufficient food form their own farm land.

\section{Discussion}

Majhi people are one of the backward caste among the indigenous peoples of Nepal. They have own language, dress, culture. They have close relationship with the rivers of Nepal. In the study area, 308 Majhi people have 93 sex ratio which is less 
than national level of sex ratio 94 . Nearly fifty percent people are in nuclear family. Similarly, their mother tongue is Majhi but 80 percent Majhipeople speak in national level. All of the Majhi people of the study area is used the Nepali language but only 29 percent speak Nepali language in national (CBS, 2014).

The main traditional occupation of the Majhi people is boating and fishing in Nepal. The study populations were engaged in agriculture (30\%); fishing and boating $(19 \%)$ in the past. But, now they are working for main sources of household income are agriculture $(71 \%)$, the foreign labour migration (17\%) and fishing (10\%) and daily wages (5\%). CBS, (2014) denoted that the 64.08 percent people are occupied in agriculture. Also annual income, land holding is increasing and occupation is continuously shifting. NLFS II estimated that "self employed without regular paid employees" accounted for $45 \%$ of the total people engaged in informal employment (CBS 2009). Gov of Nepal (2076) determined the poverty rate of Nepal is 18.7. These fact denoted that the living condition of Majhi is gradually improving but could not reached as same as national level. It is interesting to notify that their old occupation, the boating is completely replaced by others resources. The 24422 Majhi people have own language (CBS, 2014) but the study areas' people speak Nepali language. The Majhi people 61.4 percent are literate which is lower than national level 65 percent but higher than national literacy rate of Majhi 58 percent aged 6 and above (CBS, 2014).

\section{Conclusion}

The study is based on socio-economic study of Majhi community at Aatharai Rural Municipality of Terhathum District. The educational status is poor and higher level education (campus level) enrolment is completely zero. The Majhi people have been changed their occupation boating, fishing to agriculture, foreign employment which is changed their income level in positive direction. The Majhi community has high proportion of child population and low proportion of ageing population and early marriage that drive the low life expectancy of people and low status of Majhi people.

\section{References}

Central Bureau of Statistics (CBS) (2003). Population monograph of Nepal. Kathmandu: Central Bureau of Statistics.

Central Bureau of Statistics (CBS) (2009). Report on the Nepal labour force survey 2008. Kathmandu: CBS/UNDP/ILO.

Central Bureau of Statistics (CBS) (2011). An introduction to the national population and housing census 2011. National population and housing census 2011. Kathmandu: Central Bureau of Statistics.

Central Bureau of Statistics (CBS) (2014). Population monograph of Nepal vo.1. Kathmandu: Central Bureau of Statistics. 
Central Bureau of Statistics (CBS) (2014). Population monograph of Nepal vol.2. Kathmandu: Central Bureau of Statistics.

Government of Nepal (GoN) (2076). Fifteen plan 2076/77-2080/81.Kathmandu: GoN.

Population Reference Beauro (PRB) (2017). World population data sheet 2017. Retrieved from www.prb.org.

Surya, M. ( 2018). Majhi in Nepal. Retrieved from https://joshuaproject.net/people_ groups/13231/NP

United Nation Development Programme (UNDP) ( 2020). Sustsinable development goal. Retrived from www.undp.org 2076/04/01. 